\title{
Impact of Some Plant Growth Regulating Substances on the Yield and its Components of Giza179 and Giza177 Rice Cultivars under Different Irrigation Interval Treatments.

\author{
Abdel-Megeed, T. M $^{1}$; Howida B. I. El-habet ${ }^{1}$;. M. Hashem ${ }^{1}$ and Shimaa A. Badawy ${ }^{2}$ \\ 1 Rice Research\& Training Center, Field Crops Research Institute, Agriculture Research \\ center, 33717 Sakha-Kafrelsheikh. \\ ${ }^{2}$ Faculty of Agriculture, Agronomy Department, Kafrelsheikh university.
}

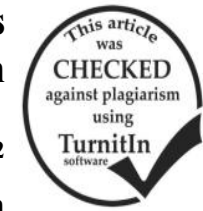

ABSTRACT

One of the main problems of lowland rice cultivation and production is the shortage of irrigation water, which effects the vegetative growth rate and the amount of yield and its component. In this study, afield experiment was conducted to find out the impact of some plant growth regulating substance on rice cultivars namely; Giza179 cultivar and Giza177 cultivar grown under different irrigation intervals in 2015 and 2016 growing season sat the farm of Agricultural Research Station, Sakha, Kafrelsheikh, Egypt. The Experiment was conducted using Randomized Complete Block Design with Strip-split plot arrangements. Main plots consisted of the three irrigation intervals namely; irrigation every 4 days (I1), irrigation every 8 days (I2) and irrigation every 12 days (I3), while sub plots devoted torice cultivars while the sub-sub plots contained the four levels of plant growth regulators: T1: spraying by cytokinein with concentration of $20 \mathrm{ppm}$, T2: spraying by abscisic acid with concentration of $15 \mathrm{ppm}$ (ABA), T3: spraying by proline with concentration of $80 \mathrm{ppm}, \mathrm{T} 4$ : control (without any spray).The recorded data were chlorophyll content (SPAD), plant height $(\mathrm{cm})$ at harvest, number of panicle $(\mathrm{m}-2)$, panicle weight $(\mathrm{g})$, number of filled grains/panicle, number of unfilled grains/panicle, 1000- grain weight $(\mathrm{g})$, grain yield $(\mathrm{t} / \mathrm{ha})$ and straw yield $(\mathrm{t} / \mathrm{ha})$. The main results indicated that irrigation every 4 and 8-days intervals cause an increase in all the previous studied characters, while irrigation every 12 days significantly reduced it. Spraying the tested rice cultivars by three growth regulators increased all studied characters as compared with control treatment. spraying Giza 179 cultivar with Cytokinin under the different irrigation intervals surpassed Giza177 cultivar and gave the highest value in all the studied characters expect 1000-grain weight followed by ABA. Spraying the two tested cultivars by Cytokinin under irrigation every 12 days which cause water stress relief the harmful of stress in the plant and increase the yield by about $3.2 \mathrm{t} / \mathrm{ha}$ specially with Giza179 cultivar as compared with control (without any growth regulator). Moreover, the application of cytokinein extend irrigation intervals from irrigation every 4 days up to irrigation every 8 days without any significant reduction in the yield. these results are benefit for farmers which safer from shortage of irrigation water in their rice field.

keywords: Rice (Oryza sativa L.), Cytokinin (CK), Abscisic acid (ABA), Proline, chlorophyll content, yield, irrigation stress.

\section{INTRODUCTION}

Rice (Oryza sativaL.) is one of the most important cereal crop in the world and it is the primary source of food and calories for about half of mankind Khush, (2005). In Egypt, Rice is one of the major water consuming crops and most of Egyptian rice genotypes are grown under continuous flooding with about $5 \mathrm{~cm}$ depth of standing water throughout the growing season. Most of Egyptian rice genotypes show better growth and higher productivity under continuous flooding conditions than ones exposed to water deficit at certain growth stages. Rice occupies about $22 \%$ of the total growing area in Egypt during summer season and it consumed about 20\% of the total water resources (Abd Allah, et al., 2009). Irrigation is an important practice in agriculture, the competition for fresh water in the development of urbanization, industry, leisure, and agriculture causes the decline of fresh water for irrigation Bergez and Nolleau (2003) and Zwart and Bastiaanssen (2004). Highest saving of irrigation water was found when irrigation intervals increased from continuous to irrigation every 12 days (El- Refaee, et al., 2012). Irrigation every 8 days produced high rice grain yield $(9.77 \mathrm{t} / \mathrm{ha})$ for Giza179 which equal about $4.10 \mathrm{t} / \mathrm{fed}$ and save water about 23.66 $\%$ (El-Habet, 2014).

Plant growth regulators are known to enhance the source-sink relationship and stimulate the translocation of photo-assimilates thereby helping in effective flower formation, fruit and seed development and ultimately enhance productivity of the crops. Growth regulators can improve the physiological efficiency including photosynthetic ability and can enhance the effective partitioning of accumulates from source and sink in the field crops (Solamani et al., 2001).

Cytokinins (CKs) promote cell division and, acting both in synergy and antagonism with other plant hormones, influence a wide range of events during plant growth. The major portion of CKs is produced in meristematic regions in the root system and transported via xylem to the shoot. These CKs, along with the locally synthesized CKs, control development and senescence of the whole plant. CKs promote leaf expansion, accumulation of chlorophyll and conversion of etioplasts into chloroplasts, and delay leaf senescence. The molecular mechanism of $\mathrm{CK}$ action is only poorly understood and an information how endogenous CKs are affected under stress is meager (Pospíšilová et al.,2000).

Plant responses to CKs are often judged from their responses to exogenously applied CKs. However, when CKs was applied and follow the plant response, it is necessary to take into consideration that exogenous CKs (natural and synthetic) can increase content of endogenous CKs by their uptake and by promotion of CK biosynthesis. On the other hand, they can increase cytokinein oxidase activity and CK degradation (Hare et al. 1997, Kamínek et al. 1997). Thus, the composition and concentration of CKs in the site of action might be quite different than in the site of application.

The plant hormone abscisic acid (ABA) plays a major role in plant responses to stress. Although rapid production of $\mathrm{ABA}$ in response to drought and salt stresses is essential to define $\mathrm{ABA}$ as a stress hormone, an equally rapid catabolism of $\mathrm{ABA}$ when such stresses are relieved is also essential in that role. Among these regulated physiological responses, the plant hormone 
abscisic acid (ABA) plays a central role. ABA is defined as a stress hormone because of its rapid accumulation in response to stresses and its mediation of many stress responses that help plant survival over the stresses. How can this substance achieve this purpose? The first prerequisite is that its production should be sensitively and rapidly triggered by the stress to avoid any inhibition of plant growth and functions under unstressed conditions. The second prerequisite is that ABA should be rapidly degraded and deactivated once the stress is relieved such that normal plant growth and functions can resume. (Zhang., et al., 2006).

Proline has been proposed to act as compatible solute that adjusts the osmotic potential in the cytoplasm. Thus, proline can be used as a metabolic marker in relation to stress(Caballero, et al.,2005). Moreover, under water stress the accumulation of total soluble sugars in different plant parts would be increased (Hu, et al., 2006). However, the rate of additional production or accumulation of proline and soluble sugar is different in different plant parts. Although plant's leaf would monitor the osmolytes components more compared to the other plant parts, sheaths account for more contents rather than blades. Of-course, the sensitivity of leaves toward water stress depends on their ages and segments of plants (Rabas,A.R. and Martin, 2003. and Cabuslay, et al., 2002).

Application of CKs can reverse leaf and fruit abscission induced by ABA or water stress, or CKs release seed dormancy in contrasts with ABA inhibition of germination. The antagonism between CKs and $\mathrm{ABA}$ may be the result of metabolic interactions. CKs share, at least in part, a common biosynthetic origin with $\mathrm{ABA}$ (Cowan et al. 1999).

Various studies show that water stress negatively affects plants including rice and reduce yields in crops. Application of hormones and growth regulators on the other hand, improves growth parameters in the plants under drought stress. Therefore, the present study aimed to study the effects of spraying different plant growth regulator on some growth parameters, yield and yield components on two rice cultivars under differentlevels of irrigation intervals (water stress).

\section{MATERIALS AND METHODS}

Afield experiment was conducted at the Experimental Farm of Sakha Agricultural Research Station, Kafrelsheikh, Egypt, during 2015 and repeated in 2016 rice growing seasons, to identify the impact of plant growth regulators i.e. Cytokinin (CK) with concentration of $20 \mathrm{ppm}$, Abscisic acid with concentration of 15 ppm (ABA), and proline (PL) with concentration of $80 \mathrm{ppm}$ on growth yield and its attributes of both rice cultivars (Giza177 and Giza179) under different irrigation intervals i.e. irrigation every 4 days (I1), irrigation every 8 days (I2) and irrigation every 12 days (I3) (water stress). The field experiments were laid out in a strip-split design with four replications. The irrigation treatments were applied in the main plots, while the two rice cultivars were placed in the sub- plots and subsub plots comprised of plant growth regulating substances(PGRs)T1: sprayingby cytokinin, T2: spraying by abscisic acid (ABA), T3: spraying by proline, T4: control (without any spray).

Rice cultivars were sprayed with plant growth regulators twice after 15 and 30 DAT. Pre-germinated seeds of both rice cultivars at the rate of $120 \mathrm{Kg} / \mathrm{ha}$, were broadcasted manually in the nursery on 10th of May in 2015 and 2016 seasons. Nitrogen (Urea $46 \%$ N), Phosphorus single super phosphate $15 \%$ at the rate of $36.89 \mathrm{~kg} \mathrm{P} 2 \mathrm{O} 5 / \mathrm{ha}$ was added to the soil before tillage and Zinc (ZnSO4)was applied as recommended. Seedlings were manually pulled and transferred to the permanent field and transplanted in $20 \times 20 \mathrm{~cm}$ between rows and hills. The sub-sub plot size was $12 \mathrm{~m} 2$. The number of seedling/hill was 2-3 seedling. Seven days after transplanting, the herbicide Saturn $50 \%$ at the rate of $4.8 \mathrm{~L}$ ha-1 was mixed with enough amount of sand to make it easy for homogenous distribution to controlled the weeds. All the other agronomic practices were applied as the recommended of RRTC during the studied seasonin the permanent fields. Plant height $(\mathrm{cm})$, chlorophyll content of flag leaf using (SPAD)chlorophyll meter Minolta camera Co. Ltd., Japan, number of panicles/m2, panicle weight (g), number of filled grains/panicle, number of unfilled grains/panicle, 1000- grain weight $(\mathrm{g})$, grain and straw yields ( $\mathrm{t} / \mathrm{ha}$ )were estimated. Representative soil samples were taken from the experimental sites at $(0-30 \mathrm{~cm})$ depth from soil Surface. Physical and chemical analysis were done and the data were recorded in Table (1) Black et al. (1965).All the collected data were subjected to statistical analysis according to procedure described by Gomez and Gomez (1984). Means were compared at $\mathrm{p}<0.05$ by the revised least significant differences (LSD), which adapted by Waller and Duncan (1969).

Table 1. Soil physical and chemical properties of the experimental sites

\begin{tabular}{|c|c|c|}
\hline \multirow{2}{*}{ Soil characteristics } & \multicolumn{2}{|c|}{ Seasons } \\
\hline & 2015 & 2016 \\
\hline & \multicolumn{2}{|c|}{ Clayey } \\
\hline Soil texture (\%) & 57.00 & 54.00 \\
\hline Clay $\%$ & 11.00 & 11.00 \\
\hline Sand $\%$ & 32.00 & 35.00 \\
\hline Silt \% & 8.05 & 8.2 \\
\hline $\mathrm{pH}(1: 2.5$ water suspension) & 2.0 & 2.05 \\
\hline \multicolumn{3}{|l|}{$\mathrm{EC}(\mathrm{dSm}-1)$} \\
\hline Organic matter & 1.65 & 1.50 \\
\hline Available $\mathrm{P}$ mg Kg $\mathrm{Kg}^{-1}$ & 14.00 & 12.00 \\
\hline Available $\mathrm{NH}_{4} \mathrm{mg} \mathrm{Kg}^{-1}$ & 13.5 & 12.60 \\
\hline Available $\mathrm{NO}_{3} \mathrm{mg} \mathrm{Kg}^{-1}$ & 10.0 & 11.80 \\
\hline Available $\mathrm{K} \mathrm{mg} \mathrm{Kg}^{-1}$ & 366 & 350 \\
\hline \multicolumn{3}{|l|}{ Cations (meq/L.) } \\
\hline $\mathrm{Ca}^{++}$ & 7.20 & 6.00 \\
\hline $\mathrm{Mg}^{++}$ & 2.60 & 1.50 \\
\hline $\mathrm{Na}^{+}$ & 12.00 & 13.00 \\
\hline $\mathrm{K}^{+}$ & 0.50 & 0.50 \\
\hline \multicolumn{3}{|l|}{ Anions (meq/L.) } \\
\hline $\mathrm{HCO}^{-}$ & 5.60 & 5.00 \\
\hline $\mathrm{Cl}-$ & 14.00 & 14.00 \\
\hline $\mathrm{SO}^{--}$ & 2.70 & 2.00 \\
\hline $\mathrm{CO}^{--}$ & 0.00 & 0.00 \\
\hline
\end{tabular}

\section{RESULTS AND DISCUSSION}

Chlorophyll content of flag leaf:

Chlorophyll content of flag leaf, plant height and number of panicles/m2 of Giza 177 and Giza179 rice cultivars as affected by different irrigation intervals, 
growth regulating substances and their interaction in 2015 and 2016 seasons are presented in table (2, 3, 4 and 5).

Data indicated that irrigation every 4 days produced the greatest chlorophyll content in the flag leaf followed by the irrigation every 8 days, while irrigation every 12 days gave the lowest value in this aspect. The decreases in chlorophyll content under the irrigation every 12 days could be attributed to water stress under this treatment which cause a decrease in chlorophyll biosciencesinside the plant celland increase the degradationin chlorophyll under the deficiency of water content. Also, the deficiency of water (water stress) inhibited the specific enzymes for biosynthesis of chlorophyll in chloroplast resulted in a decrease in the content of chlorophyll and cause senescence in rice leavesspecially flag leaf.

Data demonstrated that there were a significant differences between the two tested cultivars in chlorophyll content in the flag leaf in both studied seasons. Giza 177 cultivar gave the highest chlorophyll content in flag leaf as compared with Giza 179 cultivar in both studied seasons. It might be due to the difference in geneticconstitute. Data in the same table indicated that the foliar spray with plant growth regulators caused an increase in chlorophyll content of flag leaf. The highest values were observed when sprayed rice with both Cytokininand ABA, whilethe lowest value wasrecorded when sprayed the plants by proline or without growth regulators (control).

Table 2. Chlorophyll content of flag leaf, plant height $(\mathrm{cm})$ and number of panicle/m $\mathrm{m}^{2}$ of Giza 177 and Giza179 rice cultivars as affected by different irrigation intervals and growth regulators during 2015 and 2016 season.

\begin{tabular}{|c|c|c|c|c|c|c|}
\hline \multirow{2}{*}{ Treatments } & \multicolumn{2}{|c|}{ Chlorophyll of flag leaf (SPAD) } & \multicolumn{2}{|c|}{ Plant height (cm) } & \multicolumn{2}{|c|}{ Number of panicle $/ \mathrm{m}^{2}$} \\
\hline & $\mathbf{2 0 1 5}$ & 2016 & 2015 & 2016 & 2015 & 2016 \\
\hline \multicolumn{7}{|l|}{ Irrigation interval (A): } \\
\hline Irrigation every 4 days $\left(\mathrm{I}_{1}\right)$ & $39.666 \mathrm{a}$ & $40.016 \mathrm{a}$ & $90.93 a$ & $90.38 \mathrm{a}$ & $513.93 \mathrm{a}$ & $520.52 a$ \\
\hline Irrigation every 8 days $\left(\mathrm{I}_{2}\right)$ & $38.999 b$ & $39.349 b$ & $86.93 b$ & $84.27 b$ & $488.74 b$ & $495.33 b$ \\
\hline Irrigation every 12 days $\left(\mathrm{I}_{3}\right)$ & $36.519 \mathrm{c}$ & $36.869 \mathrm{c}$ & $84.27 \mathrm{c}$ & $82.11 \mathrm{c}$ & $400.73 \mathrm{c}$ & $407.32 \mathrm{c}$ \\
\hline F. Test & $* *$ & $* *$ & $* *$ & $* *$ & $* *$ & $* *$ \\
\hline \multicolumn{7}{|l|}{$\overline{\text { Rice varieties (B) }}$} \\
\hline Giza177 $\left(\mathrm{V}_{1}\right)$ & $39.027 \mathrm{a}$ & $39.377 \mathrm{a}$ & $89.00 \mathrm{a}$ & $86.79 a$ & $455.01 b$ & $461.60 \mathrm{~b}$ \\
\hline Giza $179\left(V_{2}\right)$ & $37.763 b$ & $38.112 b$ & $85.76 b$ & $84.39 b$ & $480.58 \mathrm{a}$ & $487.17 \mathrm{a}$ \\
\hline F. Test & $* *$ & $* *$ & $* *$ & $* *$ & $* *$ & $* *$ \\
\hline \multicolumn{7}{|l|}{ Growth regulates Treatment $(\mathrm{C})$} \\
\hline Spraying with Cytokinin $\left(\mathrm{T}_{1}\right)$ & $39.112 \mathrm{a}$ & $39.462 \mathrm{a}$ & $89.74 a$ & $87.93 a$ & $496.95 \mathrm{a}$ & $503.54 a$ \\
\hline Spraying with $\mathrm{ABA}\left(\mathrm{T}_{2}\right)$ & $38.872 \mathrm{a}$ & $39.222 \mathrm{a}$ & $87.83 \mathrm{ab}$ & $85.59 \mathrm{ab}$ & $472.12 b$ & $478.71 b$ \\
\hline Spraying with proline $\left(\mathrm{T}_{3}\right)$ & $37.943 b$ & $38.293 b$ & 86.99ab & $84.99 \mathrm{ab}$ & $460.27 \mathrm{c}$ & $466.86 \mathrm{c}$ \\
\hline Control $\left(\mathrm{T}_{4}\right)$ & $37.652 b$ & $38.002 b$ & $84.95 b$ & $83.84 b$ & $441.85 \mathrm{~d}$ & $448.44 d$ \\
\hline F. Test & $* *$ & $* *$ & $*$ & $*$ & $* *$ & $* *$ \\
\hline \multicolumn{7}{|l|}{ Interaction: } \\
\hline $\mathrm{AXB}$ & $*$ & $*$ & $*$ & $*$ & $* *$ & $* *$ \\
\hline $\mathrm{AXC}$ & $* *$ & $* *$ & $*$ & $*$ & $*$ & $*$ \\
\hline $\mathrm{BXC}$ & NS & NS & $*$ & $*$ & $* *$ & $* *$ \\
\hline AXBXC & NS & NS & NS & $\mathrm{NS}$ & $\mathrm{NS}$ & NS \\
\hline
\end{tabular}

Data in Table (3) clarified that there were a significant differences between the two tested cultivars and the different irrigation intervals. Giza177 cultivar gave the highest chlorophyll content in flag leaf under irrigation every 4 days' intervals followed by 8 days' intervals without big difference between them, while Giza179 cultivar came in the second rank after Giza177cultivar under the same two irrigation intervals and had the same trend. On contrasted irrigation, every 12 days produced the lowest value in this aspect with the two studied cultivars specially Giza 179 cultivar in the two studied seasons. It could be attributed to the deficiency in the water (water stress) which cause a decrease in chlorophyll biosynthesis inside the plant cell (in chloroplast) and also might be due to the degradation of chlorophyll under water stress (irrigation every 12 days).

Regarding the interaction effect between irrigation intervals and growth regulators in chlorophyll content of flag leaf (Table 4), data showed that irrigated rice every 4daysintervals recorded nearly the same value of chlorophyll content in flag leaf under different PGRs and control, while spraying Cytokinin or ABA under irrigation every 4 days gave the same value as irrigation every 8 days followed by proline as compared with control. On contrasted the lowest value was recorded by irrigation every 12 days because of the water deficit (water stress) which cause a reduction in biosciences of chlorophyll. Also, further, water stress usually accelerates leaf senescence. On contrast, Cytokinindelays leaf senescence due to the improve chlorophyll inside the plant cell. These findings are in close agreement with those reported by Soejima et al. 1992, Čatský et al. 1996, Naqvi 1999.

Table 3. Chlorophyll content of flag leaf, plant height (cm) and number of panicles $/ \mathrm{m}^{2}$ as affected by the interaction between different irrigation intervals and the two rice cultivars in 2015 and 2016 seasons.

Chlorophyll content of flag leaf

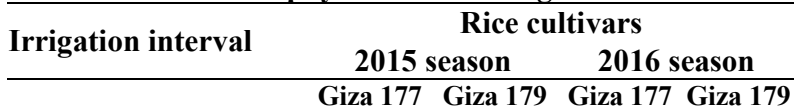

\begin{tabular}{llllll}
\hline Irrigation every 4 days $\left(\mathrm{I}_{1}\right)$ & $40.048 \mathrm{a}$ & $39.285 \mathrm{~b}$ & $40.398 \mathrm{a}$ & $39.635 \mathrm{~b}$
\end{tabular} $\begin{array}{llllll}\text { Irrigation every } 8 \text { days }\left(\mathrm{I}_{2}\right) & 39.280 \mathrm{~b} & 38.718 \mathrm{c} & 39.630 \mathrm{~b} & 39.067 \mathrm{~b}\end{array}$ $\begin{array}{lllll}\text { Irrigation every } 12 \text { days }\left(\mathrm{I}_{3}\right) & 37.753 \mathrm{~d} & 35.285 \mathrm{e} & 38.103 \mathrm{c} & 35.635 \mathrm{~d}\end{array}$ \begin{tabular}{lllll}
\hline & \multicolumn{5}{c}{ Plant height $(\mathrm{cm})$} \\
\hline Irrigationevery 4 days $\left(\mathrm{I}_{1}\right)$ & $93.42 \mathrm{a}$ & $88.45 \mathrm{ab}$ & $92.40 \mathrm{a}$ & $88.36 \mathrm{ab}$
\end{tabular} $\begin{array}{lllll}\text { Irrigationevery } 8 \text { days }\left(\mathrm{I}_{2}\right) & 88.42 \mathrm{ab} & 85.45 \mathrm{~b} & 85.17 \mathrm{ab} & 83.38 \mathrm{~b}\end{array}$ \begin{tabular}{lllll} 
Irrigationevery 12 days $\left(\mathrm{I}_{3}\right)$ & $85.17 \mathrm{~b}$ & $83.38 \mathrm{~b}$ & $82.79 \mathrm{~b}$ & $81.43 \mathrm{~b}$ \\
\hline
\end{tabular} $\frac{1}{\text { Number of panicles } / \mathrm{m} 2}$ \begin{tabular}{lllll}
\hline Irrigationevery 4 days $\left(\mathrm{I}_{1}\right)$ & $499.63 \mathrm{~b}$ & $528.23 \mathrm{a}$ & $506.22 \mathrm{~b}$ & $534.82 \mathrm{a}$
\end{tabular} $\begin{array}{lllll}\text { Irrigationevery } 8 \text { days }\left(\mathrm{I}_{2}\right) & 476.28 \mathrm{c} & 501.20 \mathrm{a} & 482.87 \mathrm{c} & 507.79 \mathrm{~b}\end{array}$ \begin{tabular}{lllll} 
Irrigationevery 12 days $\left(\mathrm{I}_{3}\right)$ & $389.13 \mathrm{e}$ & $412.33 \mathrm{~d}$ & $395.72 \mathrm{e}$ & $418.92 \mathrm{~d}$ \\
\hline
\end{tabular} 
Table 4. Chlorophyll content of flag leaf, plant height $(\mathrm{cm})$ and number of panicles $/ \mathrm{m}^{2}$ as affected by the interaction between different irrigation intervals and growth regulators in 2015 and 2016 seasons. Chlorophyll content of flag leaf

\begin{tabular}{|c|c|c|c|c|c|c|c|c|}
\hline \multirow{3}{*}{ Irrigation interval } & \multicolumn{8}{|c|}{ Plant growth regulators } \\
\hline & \multicolumn{4}{|c|}{2015 season } & \multicolumn{4}{|c|}{2016 season } \\
\hline & Cytokinin & ABA & Proline & Control & Cytokinin & ABA & Proline & Control \\
\hline Irrigationevery 4 days $\left(\mathrm{I}_{1}\right)$ & $39.87 \mathrm{a}$ & $39.66 \mathrm{a}$ & $39.63 a$ & $39.50 \mathrm{a}$ & $40.22 \mathrm{a}$ & $40.02 \mathrm{a}$ & $39.98 \mathrm{a}$ & $39.85 a$ \\
\hline Irrigationevery 8 days $\left(\mathrm{I}_{2}\right)$ & $39.86 a$ & $39.63 a$ & $38.50 \mathrm{~b}$ & $38.00 \mathrm{bc}$ & $40.22 \mathrm{a}$ & $39.98 \mathrm{a}$ & $38.85 b$ & $38.35 \mathrm{bc}$ \\
\hline Irrigationevery 12 days $\left(\mathrm{I}_{3}\right)$ & $37.60 \mathrm{~cd}$ & $37.32 \mathrm{~d}$ & $35.70 \mathrm{e}$ & $35.46 \mathrm{e}$ & $37.95 \mathrm{c}$ & $37.67 \mathrm{c}$ & $36.05 \mathrm{~d}$ & $35.81 \mathrm{~d}$ \\
\hline & \multicolumn{8}{|c|}{ Plant height $(\mathrm{cm})$} \\
\hline Irrigationevery 4 days $\left(\mathrm{I}_{1}\right)$ & $93.36 \mathrm{a}$ & $91.67 \mathrm{a}$ & $90.75 \mathrm{ab}$ & $87.95 \mathrm{abc}$ & $93.03 \mathrm{a}$ & $90.56 \mathrm{a}$ & $90.17 \mathrm{ab}$ & $87.78 \mathrm{abc}$ \\
\hline Irrigationevery 8 days $\left(\mathrm{I}_{2}\right)$ & $89.36 \mathrm{abc}$ & $87.67 \mathrm{abc}$ & $86.75 \mathrm{abc}$ & $83.95 b c$ & $86.50 \mathrm{abc}$ & $84.17 \mathrm{abc}$ & $83.47 \mathrm{abc}$ & $82.95 \mathrm{bc}$ \\
\hline Irrigationevery 12 days $\left(\mathrm{I}_{3}\right)$ & $86.50 \mathrm{abc}$ & $84.17 \mathrm{bc}$ & $83.47 \mathrm{c}$ & $82.95 \mathrm{c}$ & $84.25 \mathrm{abc}$ & $82.03 \mathrm{bc}$ & $81.34 \mathrm{c}$ & $80.81 \mathrm{c}$ \\
\hline & \multicolumn{8}{|c|}{ Number of panicles /m2 } \\
\hline Irrigationevery 4 days $\left(\mathrm{I}_{1}\right)$ & $517.10 \mathrm{a}$ & $515.00 \mathrm{a}$ & $513.15 \mathrm{a}$ & $510.45 \mathrm{ab}$ & $523.69 a$ & $521.59 \mathrm{a}$ & $519.74 a$ & $517.04 \mathrm{ab}$ \\
\hline Irrigationevery 8 days $\left(\mathrm{I}_{2}\right)$ & $514.15 a$ & $500.25 b$ & $480.30 \mathrm{c}$ & $460.25 d$ & $520.74 a$ & $506.84 b$ & $486.89 \mathrm{c}$ & $466.84 d$ \\
\hline Irrigationevery 12 days $\left(\mathrm{I}_{3}\right)$ & $459.60 \mathrm{~d}$ & $401.10 \mathrm{e}$ & $387.35 \mathrm{f}$ & $354.85 \mathrm{~g}$ & $466.19 d$ & $407.69 \mathrm{e}$ & $393.94 \mathrm{f}$ & $361.44 \mathrm{~g}$ \\
\hline
\end{tabular}

Plant height $(\mathbf{c m}):$ Plant height $(\mathrm{cm})$ of two tested rice cultivars as affected by different of both water intervals, genotypes and different plant growth regulators and their interactions in 2015 and 2016 seasons are shown in Tables(2,3,4 and 5).

Data in Table 2 show that irrigation every 12 days (water stress)significantly decreased the plant height and reached to the minimizing value, while, the tallest plant was obtained from irrigation every 4 days. The reduction in plant height was occurred when rice imposed to water stress at active tillering. This is because of low leaf water potentials and reduction in photosynthetic activity which decline because of a decrease in stomatal opening and the inhibition of chloroplast activity when rice impose to water stress beside the reduce in the length of the internodes at process which follows tillering period. Giza 177cultivar came in the first rank flowed by Giza 179cultivar which came in the second rank in plant height $(\mathrm{cm})$.

Also, Data showed that spray Cytokinin, ABA or proline gave nearly the same highest value of plant height in both seasons. Whereas, the lowest value was recorded in control (without PGRs) in the both seasons.

The interaction effect between irrigation intervals and rice cultivars are presented in Table (3). Data revealed that Giza 177cultivar and Giza 179cultivar gave nearly the same plant height and reached to the maximum valueunder treatment of irrigation every 4 days without significant difference with Giza177 cultivar under irrigation every 8days intervals in the first and second season of study. Irrigation every 12-days intervals recorded the lowest plant height $(\mathrm{cm})$ in the both seasons of study.

Data listed in Table 4 assured that there were highly significant differences in the interaction between irrigation intervals and PGR treatments in both seasons of study. Multiple range tests deemed that, spray rice with eitherCytokinin or ABA and proline improved plant height underirrigation every 4-days followed by irrigation every 8 days and 12-days. It might be due to the relief the injury of water stress specially under irrigation of 12-days. Whereas, the lowest value of plant height $(\mathrm{cm})$ was recorded under the treatmentof irrigation every 12 days due to the application of PGRswithout spraying any of PGR (control) in both seasons.

From the results presented in Table 5, data showed that a significantinteraction between rice cultivars and PGR in plant height was observed. Giza177 cultivar surpassed Giza179 cultivar and gave the tallest plant when the two cultivar sprayed with the three tested PGR. While, the lowest plant highest was found when the two tested cultivars did not receive any of PGRs (control treatment). These results were hold true in the two studied seasons. Similar findings were reported by (Bahattacharjee, et al., 1973 and De Datta, et al., 1973).

Table 5. Plant height $(\mathrm{cm})$ and number of panicles $/ \mathrm{m}^{2}$ as affected by the interaction between different growth regulators and two rice cultivars in 2015 and 2016 seasons.

\begin{tabular}{lcccc}
\hline & \multicolumn{5}{c}{ Plant height (cm) } \\
\cline { 2 - 5 } Plant growth & \multicolumn{4}{c}{ Rice cultivars } \\
\cline { 2 - 5 } regulators & 2015 season & 2016 season \\
\cline { 2 - 5 } & Giza 177 & Giza 179 & Giza 177 & Giza 179 \\
\hline Spraying with cytokinin. & $91.92 \mathrm{a}$ & $87.56 \mathrm{abc}$ & $89.89 \mathrm{a}$ & $85.96 \mathrm{abc}$ \\
Sprayingwith ABA. & $90.33 \mathrm{ab}$ & $85.34 \mathrm{bc}$ & $86.93 \mathrm{ab}$ & $84.24 \mathrm{bc}$ \\
Sprayingwith proline & $88.48 \mathrm{abc}$ & $85.50 \mathrm{bc}$ & $85.80 \mathrm{abc}$ & $84.18 \mathrm{bc}$ \\
Control & $85.26 \mathrm{bc}$ & $84.63 \mathrm{c}$ & $84.52 \mathrm{c}$ & $83.17 \mathrm{c}$ \\
\hline \multicolumn{5}{c}{ Number of panicles $/ \mathrm{m}^{2}$} \\
\hline Sprayingwith cytokinin. & $485.40 \mathrm{~b}$ & $508.50 \mathrm{a}$ & $491.99 \mathrm{~b}$ & $515.09 \mathrm{a}$ \\
Sprayingwith ABA. & $457.27 \mathrm{~d}$ & $486.97 \mathrm{~b}$ & $463.86 \mathrm{~d}$ & $493.56 \mathrm{~b}$ \\
Sprayingwith proline & $448.70 \mathrm{~d}$ & $471.83 \mathrm{c}$ & $455.29 \mathrm{~d}$ & $478.42 \mathrm{c}$ \\
Control & $428.67 \mathrm{e}$ & $455.03 \mathrm{~d}$ & $435.26 \mathrm{e}$ & $461.62 \mathrm{~d}$ \\
\hline
\end{tabular}

\section{Number of panicles $/ \mathrm{m}^{2}$ :}

Table 2 showthe number of panicles /m2of the two tested rice cultivars as affected by water intervals and different plant growth regulators during 2015 and 2016 seasons.

Data demonstrated that irrigation rice every 4 days recorded the highest number of panicles/m2 followed by irrigation every 8days while the irrigation every 12-days significantly reduced the number of panicles. It might be due to the decrease in number of tillers as result to water deficiency (water stress) under irrigation every 12-days beside the negative effect of water stress on the growth and initiation of panicles as a result to the reduction in phytochrome hormones that responsible for flowering. Also, Bahattacharjee. et al., (1973), De Datta et al., (1973) and Tantawi and Ghanem (2001) found that significant reductions in panicles numbers when rice imposed to water stress at tillering stage.

As for the difference between the two tested cultivars, data revealed that Giza 179 rice cultivar produced highe rnumber of panicles $/ \mathrm{m} 2$ than Giza177 cultivarin the both seasons. It might be mainly due to the varietal differences according to genetic background.

From the result presented in Table (2)spraying Cytokinin gave the highest number of panicles $/ \mathrm{m} 2$ followed by ABA. Whereas, control gave the lowest 
value of number of panicles $/ \mathrm{m} 2$ in both seasons. It can be easily noticed that the application of the three-plant growth regulating substance caused an increase in number of panicle as compared with control treatments.

The interaction between rice cultivars and different irrigation intervals had a significant influence on number of panicles $/ \mathrm{m} 2$. From the results presented in Table 3, it could be concluded that Giza179cultivar produced the highest number of panicles $/ \mathrm{m} 2$ under irrigation either every 4 days or every 8 days without any significant between them. While the lowest number of panicles were obtained with Giza177 cultivar when irrigated every 12 days.

Data in Table 4 show that rice plants which irrigated every 4 days and treated with different PGRs recorded the same values of number of panicles $/ \mathrm{m} 2$ when rice plants irrigated every 8 days and treatedwithCytokininwithout any significant difference between them. It means that tested rice cultivars sprayed by Cytokinin led to extend the irrigation interval from 4-days up to every 8 days consequently save reasonable amount of irrigation water without significant reduction in the sink capacity (No. of panicles). While the lowest value of number of panicles/m2 were found with irrigation every 12 days under control treatment (without any spray). Such findings had also been pointed out by Bahattacharjee. et al., (1973) and De Datta et al., (1973).

Data in Table 5 show the interaction between rice cultivars and the tested plant growth regulator (PGR). Spray Giza 179 cultivar with Cytokinin gave the highest number of panicles $/ \mathrm{m} 2$ followed by ABA treatment.
Whereas, the lowest value was recorded with Giza 177 cultivar under control treatment.

\section{Panicle weight (g):}

Panicle weight, number of filled grains/panicle and number of unfilled grains/panicle of the two tested rice cultivars as influenced by various irrigation intervals and different plant growth regulators, as well as their interactions in 2015 and 2016 seasons are listed in Tables (6,7,8 and 9).

Data in Table 6 indicated that the highest weight of panicle was obtained when rice irrigated every 4 days followed by irrigation every 8 days, while the lowest value was obtained with the irrigation every 12 days in both seasons of study. Similar results were reported by Rahman, et al., (2002), Bahattacharjee. et al., (1973) and De Datta et al., (1973).

Data in Table 6 show that Giza 179 cultivar gave the highest value of panicle weight (g) as compared with Giza177 cultivar in the first and second seasons. It might be due to the difference in the genetic constitution. The obtained results are in good agreement with those reported by Hany, et al., (2011), Metwally, et al., (2016) and Hashem, et al., (2016).

Data in the same Table revealed that Plant growth regulators caused an increase in panicle weight as compared with control. The highest panicle weight (g) was found when rice plants sprayed with Cytokinin followed by ABA which gave nearly the same in this aspect. Similar results were observed in the two seasons of study.

Table 6. Panicle weight/g, number of filled grains/panicle and number of unfilled grains /panicle of rice cultivars as affected by both different irrigation intervals and growth regulates during 2015 and 2016 season.

\begin{tabular}{|c|c|c|c|c|c|c|}
\hline \multirow{2}{*}{ Treatments } & \multicolumn{2}{|c|}{ Panicle weight/g } & \multicolumn{4}{|c|}{ Number of filled grains/panicle Number of unfilled grains /panicle } \\
\hline & 2015 & 2016 & 2015 & 2016 & $\mathbf{2 0 1 5}$ & 2016 \\
\hline Irrigation every 4 days $\left(\mathrm{I}_{1}\right)$ & $3.375 \mathrm{a}$ & $3.526 a$ & $120.573 a$ & $122.814 \mathrm{a}$ & $5.346 b$ & $6.996 \mathrm{~b}$ \\
\hline Irrigationevery 8 days $\left(\mathrm{I}_{2}\right)$ & $3.017 \mathrm{~b}$ & $3.169 \mathrm{~b}$ & $109.568 b$ & $111.807 \mathrm{~b}$ & $6.266 \mathrm{~b}$ & $7.916 \mathrm{~b}$ \\
\hline Irrigationevery 12 days $\left(\mathrm{I}_{3}\right)$ & $2.426 \mathrm{c}$ & $2.579 \mathrm{c}$ & $89.115 \mathrm{c}$ & $91.355 \mathrm{c}$ & $8.052 \mathrm{a}$ & $9.703 \mathrm{a}$ \\
\hline F. Test & $* *$ & $* *$ & $* *$ & $* *$ & $* *$ & $* *$ \\
\hline \multicolumn{7}{|l|}{ Rice varieties (B) } \\
\hline Giza177 $\left(\mathrm{V}_{1}\right)$ & $2.738 \mathrm{~b}$ & $2.889 \mathrm{~b}$ & $100.334 b$ & $102.575 b$ & $5.305 b$ & $6.955 b$ \\
\hline Giza $179\left(V_{2}\right)$ & $3.141 \mathrm{a}$ & $3.293 \mathrm{a}$ & $112.503 \mathrm{a}$ & $114.742 \mathrm{a}$ & $7.805 \mathrm{a}$ & $9.455 \mathrm{a}$ \\
\hline F. Test & $* *$ & $* *$ & $* *$ & $* *$ & $* *$ & $* *$ \\
\hline \multicolumn{7}{|l|}{ Growth regulates Treatment (C) } \\
\hline Spraying with cytokinin. & $3.247 \mathrm{a}$ & $3.397 \mathrm{a}$ & $114.433 a$ & $116.673 a$ & $5.575 \mathrm{~d}$ & $7.225 \mathrm{c}$ \\
\hline Sprayingwith ABA. & $3.033 \mathrm{ab}$ & $3.185 \mathrm{ab}$ & $108.437 b$ & $110.677 b$ & $6.323 c$ & $7.973 \mathrm{~b}$ \\
\hline Sprayingwith proline & $2.849 \mathrm{bc}$ & $3.006 \mathrm{bc}$ & $103.817 \mathrm{c}$ & $106.058 \mathrm{c}$ & $6.765 b$ & $8.415 b$ \\
\hline Control & $2.628 c$ & $2.778 \mathrm{c}$ & $98.987 \mathrm{~d}$ & $101.227 \mathrm{~d}$ & 7.557a & $9.207 \mathrm{a}$ \\
\hline F. Test & $*$ & $*$ & $*$ & $*$ & $* *$ & $* *$ \\
\hline \multicolumn{7}{|l|}{ Interaction: } \\
\hline AXB & $*$ & $*$ & $* *$ & $* *$ & $* *$ & $* *$ \\
\hline AXC & $*$ & $*$ & $*$ & $*$ & $* *$ & $* *$ \\
\hline $\mathrm{BXC}$ & $*$ & $*$ & $* *$ & $* *$ & $* *$ & $* *$ \\
\hline $\mathrm{AXBXC}$ & NS & NS & NS & NS & NS & NS \\
\hline
\end{tabular}

Data in Table 7 show that a significant interaction between irrigation intervals and rice cultivars in panicle weight wasobserved in both seasons of study. Data revealed that Giza 179 cultivar produced the highest panicle weight under irrigation every 4 days followed by irrigation every 8 days, while Giza177 cultivar came in the second rank after Giza179 cultivar. Whereas, the lowest value of panicle weight was observed with Giza 177 cultivarwhen irrigated every 12 days. It can be noticed that Giza 179 cultivar surpassed Giza177 under all the tested irrigation intervals and produced heavier weight of panicle. It means that Giza179 cultivar more tolerant to water shortage than Giza177 cultivar.

Regarding the interaction effect among irrigation treatments and plant growth regulators (PGR), data in Table 8 show that foliar application of any of plant growth regulators under either the irrigation every 4-daysor 8-days recorded the highest values of panicle weight except proline in the two studied seasons. It can be easily observed that there was any significant difference between the irrigation every 4-days and 8-days intervals in panicle weight when treated rice by Cytokinin or ABA. It might be due to the role of these substances to help the plant for keeping the water inside the cell more time consequently extend the period of irrigation intervals that led to save reasonable amount of irrigation water. These results are in 
good agreement with those reported by POSPÍŠILOVÁ, et al., (2000) and Soejima et al. 1992.

Data in Table 9 showed that a significant interaction between rice cultivars and PGR in panicle weight were recorded in both seasons of study. Data revealed that sprayed the tested cultivars by the growth regulating substance under study caused an increase in the weight of panicles as compared with control.Giza 179 cultivar surpassed Giza177 cultivar and gave the heaviest weight of panicle when sprayed by Cytokinin followed by $\mathrm{ABA}$ and proline in the two seasons of study. The same trend was found with Giza177 cultivar. From the previous data, it can be noticed that Giza 179 cultivar responded more to PGR than Giza 177 cultivar. The lowest value of panicle weight was recorded with Giza177 cultivar under control treatment (without PGR).

Table7. Panicle weight (g), number of filled grains/panicle and number of unfilled grains/panicles as affected by the interaction between different irrigation intervals and the two rice cultivars in 2015 and 2016 seasons. Panicle weight (g)

\begin{tabular}{lcccc}
\hline \multicolumn{5}{c}{ Panicle weight (g) } \\
\cline { 2 - 5 } Irrigation interval & \multicolumn{4}{c}{ Rice cultivars } \\
\cline { 2 - 5 } & Giza 177 season & Giza 179 & Giza 177 & Giza 179 \\
\hline Irrigation every 4 days $\left(\mathrm{I}_{1}\right)$ & $3.158 \mathrm{~b}$ & $3.592 \mathrm{a}$ & $3.307 \mathrm{ab}$ & $3.745 \mathrm{a}$ \\
Irrigationevery 8 days $\left(\mathrm{I}_{2}\right)$ & $2.868 \mathrm{bc}$ & $3.165 \mathrm{~b}$ & $3.021 \mathrm{bc}$ & $3.317 \mathrm{ab}$ \\
Irrigationevery 12 days $\left(\mathrm{I}_{3}\right)$ & $2.188 \mathrm{~d}$ & $2.665 \mathrm{c}$ & $2.340 \mathrm{~d}$ & $2.817 \mathrm{c}$ \\
\hline \multicolumn{5}{c}{ Number of filled grains/panicle } \\
Irrigationevery 4 days $\left(\mathrm{I}_{1}\right)$ & $110.130 \mathrm{c}$ & $131.015 \mathrm{a}$ & $112.372 \mathrm{c}$ & $133.255 \mathrm{a}$ \\
Irrigationevery 8 days $\left(\mathrm{I}_{2}\right)$ & $103.273 \mathrm{~d}$ & $115.863 \mathrm{~b}$ & $105.512 \mathrm{~d}$ & $118.102 \mathrm{~b}$ \\
Irrigationevery 12 days $\left(\mathrm{I}_{3}\right)$ & $87.600 \mathrm{f}$ & $90.630 \mathrm{e}$ & $89.840 \mathrm{f}$ & $92.870 \mathrm{e}$ \\
\hline \multicolumn{5}{c}{ Number of unfilled grains/panicle } \\
Irrigationevery 4 days $\left(\mathrm{I}_{1}\right)$ & $4.405 \mathrm{e}$ & $6.287 \mathrm{c}$ & $6.055 \mathrm{~d}$ & $7.938 \mathrm{bc}$ \\
Irrigationevery 8 days $\left(\mathrm{I}_{2}\right)$ & $5.525 \mathrm{~d}$ & $7.007 \mathrm{~b}$ & $7.175 \mathrm{c}$ & $8.658 \mathrm{~b}$ \\
Irrigationevery 12 days $\left(\mathrm{I}_{3}\right)$ & $5.985 \mathrm{~cd}$ & $10.120 \mathrm{a}$ & $7.635 \mathrm{bc}$ & $11.770 \mathrm{a}$ \\
\hline
\end{tabular}

Table 8. Panicle weight (g), number of filled grains/panicle and number of unfilled grains/panicles as affected by the interaction between different irrigation intervals and growth regulators in 2015 and 2016 seasons.

\begin{tabular}{|c|c|c|c|c|c|c|c|c|}
\hline \multicolumn{9}{|c|}{ Panicle weight (g) } \\
\hline \multirow{3}{*}{ Irrigation interval } & \multicolumn{8}{|c|}{ Plant growth regulators } \\
\hline & \multicolumn{4}{|c|}{2015 season } & \multicolumn{4}{|c|}{2016 season } \\
\hline & Cytokinin & ABA & Proline & Control & Cytokinin & ABA & Proline & Control \\
\hline Irrigation every 4 days $\left(\mathrm{I}_{1}\right)$ & $3.505 \mathrm{a}$ & $3.435 \mathrm{ab}$ & $3.335 \mathrm{a}-\mathrm{c}$ & $3.225 \mathrm{a}-\mathrm{c}$ & $3.655 \mathrm{a}$ & $3.585 \mathrm{a}$ & $3.490 \mathrm{ab}$ & $3.375 \mathrm{ab}$ \\
\hline Irrigationevery 8 days $\left(\mathrm{I}_{2}\right)$ & $3.400 \mathrm{ab}$ & $3.235 \mathrm{a}-\mathrm{c}$ & $2.922 \mathrm{~b}-\mathrm{d}$ & $2.510 \mathrm{de}$ & $3.550 \mathrm{ab}$ & $3.390 \mathrm{ab}$ & $3.077 \mathrm{a}-\mathrm{c}$ & $2.660 \mathrm{c}-\mathrm{e}$ \\
\hline \multirow[t]{2}{*}{ Irrigationevery 12 days $\left(\mathrm{I}_{3}\right)$} & $2.835 \mathrm{~cd}$ & $2.430 \mathrm{de}$ & $2.290 \mathrm{e}$ & $2.150 \mathrm{e}$ & $2.985 \mathrm{~b}-\mathrm{d}$ & $2.580 \mathrm{c}-\mathrm{e}$ & $2.450 \mathrm{de}$ & $2.300 \mathrm{e}$ \\
\hline & \multicolumn{8}{|c|}{ Number of filled grains/panicle } \\
\hline Irrigationevery 4 days $\left(\mathrm{I}_{1}\right)$ & $123.70 \mathrm{a}$ & $120.55 \mathrm{c}$ & $119.75 d$ & $118.29 \mathrm{e}$ & $125.940 \mathrm{a}$ & $122.790 \mathrm{bc}$ & $121.995 \mathrm{~cd}$ & $120.530 \mathrm{~d}$ \\
\hline Irrigationevery 8 days $\left(\mathrm{I}_{2}\right)$ & $122.28 b$ & $114.35 \mathrm{f}$ & $104.69 \mathrm{~g}$ & $96.96 \mathrm{~h}$ & $124.520 \mathrm{ab}$ & $116.585 \mathrm{e}$ & $106.925 \mathrm{f}$ & $99.200 \mathrm{~g}$ \\
\hline \multirow[t]{2}{*}{ 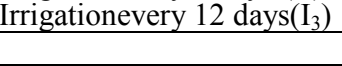 } & $97.32 \mathrm{~h}$ & $90.42 \mathrm{i}$ & $87.02 \mathrm{j}$ & $81.71 \mathrm{k}$ & $99.560 \mathrm{~g}$ & $92.655 \mathrm{~h}$ & $89.255 \mathrm{i}$ & $83.950 \mathrm{j}$ \\
\hline & \multicolumn{8}{|c|}{ Number of unfilled grains/panicle } \\
\hline Irrigationevery 4 days $\left(\mathrm{I}_{1}\right)$ & $5.430 \mathrm{fg}$ & $5.365 \mathrm{~g}$ & $5.330 \mathrm{~g}$ & $5.260 \mathrm{~g}$ & $7.080 \mathrm{e}$ & $7.015 \mathrm{e}$ & $6.980 \mathrm{e}$ & $6.910 \mathrm{e}$ \\
\hline Irrigationevery 8 days $\left(\mathrm{I}_{2}\right)$ & $5.360 \mathrm{~g}$ & $6.105 \mathrm{ef}$ & $6.615 \mathrm{de}$ & $6.985 \mathrm{~cd}$ & $7.010 \mathrm{e}$ & $7.755 \mathrm{de}$ & $8.265 \mathrm{c}-\mathrm{e}$ & $8.635 \mathrm{~cd}$ \\
\hline Irrigationevery 12 days $\left(\mathrm{I}_{3}\right)$ & $5.935 \mathrm{e}-\mathrm{g}$ & $7.500 \mathrm{c}$ & $8.350 \mathrm{~b}$ & $10.425 \mathrm{a}$ & $7.585 \mathrm{de}$ & $9.150 \mathrm{bc}$ & $10.000 \mathrm{~b}$ & $12.075 \mathrm{a}$ \\
\hline
\end{tabular}

Number of filled grains /panicle:

Within irrigation intervals, data in Table 6 clarified that irrigation every 4 days produced the greatest number of filled grains/panicle followed by irrigation every 8 days while irrigation every 12 days gave the least because of the injury of water stress under this treatment. These results are in agreement with these detected by Rahman, et al., (2002), and Tantawi, and Ghanem, (2001).Data pronounced in Table 6 show that, highly significant differences between the two cultivars were found in filled grains/panicle in the two seasons. Giza179 cultivar gave higher number of filled grains/panicle than Giza 177 cultivar in the two seasons of study. The obtained data are in good agreement with those reported by Metwally, et al., (2016) and Hashem, et al., (2016)

Data presented in Table 6assert that there were a significant differences were found among the tested PGRs on number of filled grains/panicle in both seasons of study. Within various PGRs application, plants which spraying with Cytokinin gave the highest value of number of filled grains/panicle followed by spraying ABA which gave nearly the same value of number of filled grains/panicle through the two seasons under study. The lowest number of filled grains was obtained when rice did not receive any of PGR (control). These results are in coincidence with that reported by Morris, et al., (1993) and Saha et al., (1986).

The interaction effect between different irrigation intervals and rice cultivars had a significant effect on number of filled grains/panicle (Table 7). Data indicated that the highest number of filled grains were found when Giza179 cultivar was irrigated every 4 days followed by irrigation every 8 days, while the irrigation every 12 days significantly reduced the value in this respect in the two studied seasons.

Table 9. Panicle weight (g), number of filled grains/panicle and number of unfilled grains/panicle as affected by the interaction between different growth regulators and the two rice cultivars in 2015 and 2016 seasons.

\begin{tabular}{|c|c|c|c|c|}
\hline \multicolumn{5}{|c|}{ Panicle weight $(\mathrm{g})$} \\
\hline \multirow{3}{*}{ Irrigation interval } & \multicolumn{4}{|c|}{ Rice cultivars } \\
\hline & \multicolumn{2}{|c|}{2015 season } & \multicolumn{2}{|c|}{2016 season } \\
\hline & Giza 177 & Giza 179 & Giza 177 & Giza 179 \\
\hline tokinin. & & & $3.150 \mathrm{ab}$ & \\
\hline & & & $2.897 \mathrm{~b}$ & \\
\hline & & & $61 \mathrm{~b}$ & \\
\hline & $2.500 \mathrm{~d}$ & $2.757 \mathrm{~cd}$ & $2.650 \mathrm{~b}$ & $07 \mathrm{~b}$ \\
\hline \multicolumn{5}{|c|}{ Number of filled grains/panicle } \\
\hline & \multicolumn{4}{|c|}{$106.110 \mathrm{~d} 122.757 \mathrm{a} 108.350 \mathrm{~d} 124.997 \mathrm{a}$} \\
\hline & \multicolumn{4}{|c|}{$102.453 \mathrm{f} 114.420 \mathrm{~b} 104.693 \mathrm{e} 116.660 \mathrm{~b}$} \\
\hline & \multirow{2}{*}{\multicolumn{4}{|c|}{$\begin{array}{ll}98.173 \mathrm{~g} & 10 \\
94600 \mathrm{~h} & 10\end{array}$}} \\
\hline & & $103.373 \mathrm{e}$ & $96.840 \mathrm{~g}$ & 105.613 \\
\hline \multirow{5}{*}{$\begin{array}{l}\text { Sprayingwith cytokinin. } \\
\text { Sprayingwith ABA. } \\
\text { Sprayingwith proline } \\
\text { Control }\end{array}$} & \multicolumn{4}{|c|}{ Number of unfilled grains/panicle } \\
\hline & & & & \\
\hline & & & $6.923 \mathrm{ef}$ & $9.023 \mathrm{~b}$ \\
\hline & & & & 9.600 \\
\hline & $5.877 \mathrm{e}$ & $9.237 \mathrm{a}$ & $7.527 \mathrm{de}$ & 10.887 \\
\hline
\end{tabular}

From the data presented in Table 8 , application of Cytokinin under irrigation every 4-daysproduced the highest value of number of filled grains followed by irrigation every 8 days and surpassed both $\mathrm{ABA}$ and Proline which perform the same trend. It can be also, noticed that the application of any of PGR to the tested cultivars caused an increase in number of filled grains as compared with control. The promoting effect of PGRs under irrigation intervals on 
number of filled grain /panicle were reported by Salehi Gharaviran, et al., (2014), Xie, et al., (2004), Yang, et al., (2002) and Morris, et al., (2005)

The interaction effect between rice cultivars and PGRs had a significant influence on number of filled grains/panicle (Table 9). Data demonstrated that among all treatments, Giza 179 cultivar show superiority on number of filled grains/panicle when sprayed with Cytokinin followed by $\mathrm{ABA}$ as compared with giza177 cultivar under the PGR treatments. On the other hand, the lowest value of number of filled grains/panicle was recoded with control treatment.

Number of unfilled grains/panicle:

Data in Table 6 clearly assure that, irrigation every 12 days showed a marked superiority and gave the highest in number of unfilled grains/panicle followed by irrigation every 4 and 8 days which gave nearly the same value in this aspect in both studied seasons.

Significant differences were found between rice cultivars in terms of their number of unfilled grains/panicle in both studied seasons (Table 6).Data revealed clearly that Giza 179 cultivar produced the highest number of unfilled grains/panicle, while Giza177cultivar gave the lowest values of number of unfilled grains/panicle in both studied seasons. The results were supported by Hashem, et al., (2016), Rahman, et al., (2002), and Tantawi, and Ghanem, (2001).

There were a highly significant differences among all plant growth regulators innumber of unfilled grains/panicle in both seasons of study as presented in Table 6.Data revealed that, rice plants minimized their number of unfilled grains/panicle when sprayed by the different PGRs under study as compared with control which gave the highest number of unfilled grains/panicle. Spraying Cytokinin (CK)gave the lowest number of unfilled grains/panicle, while both ABA and proline gave higher value than cytokininin this respect.

Regarding to the interaction between rice cultivars and different irrigation intervals, data in Table 7 showed that
Giza 179cultivar gave the highest number of unfilled grains/panicle under all the irrigation every 12-days treatment than Giza177 cultivar in the two studied seasons. The highest number of unfilled grains/panicle was obtained from Giza179 cultivar under the irrigation every 12 days followed by irrigation every 8 days, while the irrigation every 4 days gave the least. The same trend was observed with Giza177 cultivar under the same irrigate treatments.

The interaction between PGRs and irrigation intervals in number of unfilled grains/panicle is presented in Table (8). Data indicated that application of the tested PGRs minimized the number of unfilled grains under all the irrigation treatments as compared with control, while the lowest value was observed with Cytokinin under irrigation every 4 days. On the other side the highest value was found with control under irrigation every 12-days. The other treatments came in between. These results are conformity with those of Salehi Gharaviran, et al., (2014) and Jianchang Yang et al., (2000).

Regarding the interaction effect of rice cultivars and different plant growth regulators (Table9), it is obviously clear that spraying Cytokinin gave the lowest value of number of unfilled grains/panicle with Giza 177 cultivar, while the highest value of number of unfilled grains/panicle was recorded with Giza 179 cultivar under control treatment. It can be observed that the application PGRs reduced the number of unfilled grains as compared with control. Cytokinin decreased the unfilled grains followed by ABA and proline as compared with control.

\section{Thousand grain weight/g:}

Results presented in Table 10 conclude that the thousand-grain weight (g) had insignificant differences among the water intervals, the two rice cultivars and also, the different plant growth regulators under study. These results were hold true in the two studied seasons.

Table 10. Thousand grain weight/g, grain yield (t/ha) and straw yield (t/ha) of both rice cultivars as affected by different Irrigation intervals and different growth regulator during 2015 and 2016 seasons.

\begin{tabular}{|c|c|c|c|c|c|c|}
\hline \multirow{2}{*}{ Treatments } & \multicolumn{2}{|c|}{ Thousand grain weight/g } & \multicolumn{2}{|c|}{ Grain yield (t/ha) } & \multicolumn{2}{|c|}{ Straw yield (t/ha) } \\
\hline & 2015 & 2016 & 2015 & 2016 & 2015 & 2016 \\
\hline Irrigation interval (A): & & & & & & \\
\hline Irrigation every 4 days $\left(\mathrm{I}_{1}\right)$ & 26.67 & 25.47 & $9.588 \mathrm{a}$ & $10.099 \mathrm{a}$ & $10.898 \mathrm{a}$ & $11.778 \mathrm{a}$ \\
\hline Irrigationevery 8 days $\left(\mathrm{I}_{2}\right)$ & 27.08 & 25.84 & $8.782 \mathrm{a}$ & $9.292 \mathrm{a}$ & $10.025 b$ & $10.905 \mathrm{~b}$ \\
\hline Irrigationevery 12 days $\left(\mathrm{I}_{3}\right)$ & 27.34 & 26.14 & $6.368 \mathrm{~b}$ & $6.878 \mathrm{~b}$ & $7.834 \mathrm{c}$ & $8.714 \mathrm{c}$ \\
\hline F. Test & NS & NS & $* *$ & $* *$ & $* *$ & ** \\
\hline Rice varieties (B) & & & & & & \\
\hline Giza177 $\left(\mathrm{V}_{1}\right)$ & 27.71 & 26.48 & $7.852 \mathrm{~b}$ & $8.362 b$ & $9.056 \mathrm{~b}$ & $9.936 \mathrm{~b}$ \\
\hline Giza $179\left(\mathrm{~V}_{2}\right)$ & 26.35 & 25.15 & $8.640 \mathrm{a}$ & $9.150 \mathrm{a}$ & $10.115 \mathrm{a}$ & $10.995 \mathrm{a}$ \\
\hline F. Test & NS & $\mathrm{NS}$ & $* *$ & $* *$ & $* *$ & $* *$ \\
\hline Growth regulates Treatment (C) & & & & & & \\
\hline Spraying with cytokinin. & 26.13 & 24.89 & $9.067 \mathrm{a}$ & $9.577 \mathrm{a}$ & $10.361 \mathrm{a}$ & $11.241 \mathrm{a}$ \\
\hline Spraying with ABA. & 26.82 & 25.62 & $8.581 \mathrm{~b}$ & $9.091 \mathrm{~b}$ & $9.926 \mathrm{~b}$ & $10.806 \mathrm{~b}$ \\
\hline Spraying with proline & 27.33 & 6.13 & $7.874 \mathrm{c}$ & $8.384 \mathrm{c}$ & $9.372 \mathrm{c}$ & $10.253 \mathrm{c}$ \\
\hline Control & 27.83 & 26.63 & $7.464 d$ & $7.974 \mathrm{~d}$ & $8.684 \mathrm{~d}$ & $9.564 d$ \\
\hline F. Test & $\mathrm{NS}$ & NS & $* *$ & $* *$ & $* *$ & $* *$ \\
\hline Interaction: & & & & & & \\
\hline $\mathrm{AXB}$ & NS & NS & ** & ** & ** & ** \\
\hline $\mathrm{AXC}$ & NS & NS & ** & ** & ** & ** \\
\hline $\mathrm{BXC}$ & NS & NS & $*$ & $*$ & $*$ & $*$ \\
\hline $\mathrm{AXBXC}$ & NS & NS & * & * & NS & NS \\
\hline
\end{tabular}

\section{Grain yield (t/ha):}

From the data presented in Table 10, it could be observed that irrigation every 4 days and 8 days intervals gave the greatest grain yield without any significant difference between them, while the irrigation every 12 days significantly reduced the grain yield in the two studied seasons. It means that irrigation every 8 days is quiteenough for producing the maximum grain yield. On the other side the reduction in grain yield under irrigation every 12 days could be attributed to the water stress which cause a 
decreases in both number of tillers and panicles, LAI, chlorophyll content, water and nutrient uptake as well as the shrinking in cell protoplasm, cell division and elongation consequently cause a reduction in the morphological and physiological process in the plant such as photosynthesis's and its assimilates resulted in a decrease in filling percentage and rates which produced low panicle and 1000-grain weight that cause a significant reduction in the grain yield.There was a linear relationship between available water and yield, where reduction in available water limits evapotranspiration and consequently reduced yield, as reported by several researchers Shani, and Dudley, (2001) and Sokoto and Muhammad (2014),Boonjung, and Fukai, (1996) reported that water stress at filling grains period with acceleration in ripening time, casing to a decreasing growth duration period and which led to a reduction in grain filling.

Data in the same Table show that Giza 179cultivar recorded the highest value of grain yield as compared with Giza 177 cultivar. It might be due to the differences in genetic constitution. The obtained data are in full agreement with those reported by Hany, et al., (2011), Metwally, et al., (2016) and Hashem, et al., (2016)

Data in Table 10 reveal the application Cytokininincreased grain yield followed by ABA, while proline reduced the grain yield and gave the same as control.

Regarding the interaction effect between water treatment and rice cultivars on grain yield, data presented in Table 11 indicated that Giza 179 cultivar gave the highest grain yield under irrigation every 4 days followed by irrigation every 8 days without any significant difference between them in the two studied seasons. The lowest grain yield was recorded by Giza 177 cultivar when irrigated every 12 days in both seasons.

Table 11. Grain yield (t/ha) and straw yield (t/ha) as affected by the interaction between different irrigation intervals and the two rice cultivars in 2015 and 2016 seasons. Grain yield (t/ha)

\begin{tabular}{lcccc}
\hline \multicolumn{5}{c}{ Grain yield (t/ha) } \\
\cline { 2 - 5 } Irrigation interval & \multicolumn{4}{c}{ Rice cultivars } \\
\cline { 2 - 5 } & $\mathbf{2 0 1 5}$ season & $\mathbf{2 0 1 6}$ season \\
\cline { 2 - 5 } & $\mathbf{1 7 7}$ & $\mathbf{1 7 9}$ & $\mathbf{1 7 7}$ & $\mathbf{1 7 9}$ \\
\hline Irrigate every 4 days $\left(\mathrm{I}_{1}\right)$ & & & & \\
Irrigate every 8 days $\left(\mathrm{I}_{2}\right)$ & $8.990 \mathrm{~b}$ & $10.187 \mathrm{a}$ & $9.500 \mathrm{~b}$ & $10.697 \mathrm{a}$ \\
Irrigate every 12 & $8.425 \mathrm{c}$ & $9.140 \mathrm{~b}$ & $8.935 \mathrm{c}$ & $9.650 \mathrm{~b}$ \\
days $\left(\mathrm{I}_{3}\right)$ & $6.142 \mathrm{~d}$ & $6.593 \mathrm{~d}$ & $6.652 \mathrm{~d}$ & $7.103 \mathrm{~d}$ \\
\hline & \multicolumn{4}{c}{ Straw yield $(\mathrm{t} / \mathrm{ha})$} \\
Irrigate every 4 days $\left(\mathrm{I}_{1}\right)$ & \multicolumn{4}{c}{} \\
Irrigate every 8 days $\left(\mathrm{I}_{2}\right)$ & $10.145 \mathrm{c}$ & $11.651 \mathrm{a}$ & $11.025 \mathrm{c}$ & $12.530 \mathrm{a}$ \\
Irrigate every 12 & $9.203 \mathrm{~d}$ & $10.848 \mathrm{~b}$ & $10.083 \mathrm{~d}$ & $11.728 \mathrm{~b}$ \\
days $\left(\mathrm{I}_{3}\right)$ & $7.820 \mathrm{e}$ & $7.848 \mathrm{e}$ & $8.700 \mathrm{e}$ & $8.728 \mathrm{e}$ \\
\hline
\end{tabular}

Data listed in Table 12 revealed that statistical differences were found in grain yield due to the interaction between different irrigation intervals and various plant growth regulators in the both seasons. Spraying Cytokinin gave the highest grain yield under irrigation every 4 and 8 days without any significant difference between them, while the lowest grain yield was recorded under irrigation every 12 days. As reported by previous studies, spraying of Cytokinin (CK) on the grains during the growth stage leads to increase in Cytokinin (CK)in these organs. Increased Cytokinin (CK)concentration in seeds during cell division caused increase in the number of endospermic cells which had positive correlation with the increase in grain yield Morris, et al., (2005). The same trend was observed with ABA specially in 2016 seasons. It can be observed that under irrigation every 4 days there were not any significant differences among all the tested PGRs and control because of there was not any water stress. It is important to observed that Cytokinin relief the harmful of water stress under irrigation every 12 days followed by $\mathrm{ABA}$ and proline as compared with control in the two studied seasons. Cytokinin is syntheses in rice roots and directly increase the root depth and volume and its viability as a result to free amino acid metabolism. The cytokinin translocate to the rice shoots and indirectly controlled protein metabolism and chlorophyll biosynthesis as well as the increases in cell division and elongation, also, the cytokinin inhibit the senescence of leaves and increase the viability of leaves especially flag leaf and both the second and third leaves which cause an increase in photosynthesis and its product (assimilates) resulted inincreased filling \% that produce the heavier grains. Also, cytokinin concentration was high in the spikelets during filling period and cause an increase in cell division and elongation in the spikelets and then reached to the minimum concentration at the end of filling period.According to the findings of Kermode et al. (1989) and Yang et al. (2003)they found that the increase in ABA concentration at the beginning of period cell division decreased the significantly cell division. Also,ABA, contrary to $\mathrm{CK}$, can reduce the grain filling period via stimulation of aging Nooden., (1988) resulting in grain yield loss. Finally, it can be assumed that $\mathrm{ABA}$, contrary to Cytokinin (CK), a decreases the formation of endospermic cells of the seeds at first growth stage of seeds leading to decrease in grain yield due to source weakness in photosynthesis storage.

Proline is accumulated under a biotic stress and cause an increase in osmatic potential in plant cell to face the osmatic pressure outside the plant and also supply the plant with nitrogen.

Table 12. Grain yield ( $\mathrm{t} / \mathrm{ha}$ ) and straw yield $(\mathrm{t} / \mathrm{ha}$ ) as affected by the interaction between different irrigation intervals and different growth regulatorsin 2015 and 2016 seasons.

\begin{tabular}{|c|c|c|c|c|c|c|c|c|}
\hline \multicolumn{9}{|c|}{ Grain yield (t/ha) } \\
\hline \multirow{3}{*}{ Irrigation interval } & \multicolumn{8}{|c|}{ Rice cultivars } \\
\hline & \multicolumn{4}{|c|}{2015 season } & \multicolumn{4}{|c|}{2016 season } \\
\hline & Cytokine & ABA & Proline & Control & Cytokine & ABA & Proline & Control \\
\hline Irrigate every 4 days $\left(\mathrm{I}_{1}\right)$ & $9.689 \mathrm{a}$ & $9.610 \mathrm{ab}$ & $9.605 \mathrm{ab}$ & $9.450 \mathrm{ab}$ & $10.200 \mathrm{a}$ & $10.120 \mathrm{a}$ & $10.115 \mathrm{a}$ & $9.960 \mathrm{a}$ \\
\hline Irrigate every 8 days $\left(\mathrm{I}_{2}\right)$ & $9.600 \mathrm{ab}$ & $8.975 b c$ & $8.390 \mathrm{~cd}$ & $8.165 \mathrm{~d}$ & $10.110 \mathrm{a}$ & $9.485 \mathrm{ab}$ & $8.900 \mathrm{bc}$ & $8.675 \mathrm{c}$ \\
\hline Irrigate every 12 days $\left(\mathrm{I}_{3}\right)$ & $7.910 \mathrm{~d}$ & $7.157 \mathrm{e}$ & $5.628 \mathrm{f}$ & $4.777 \mathrm{~g}$ & $8.420 \mathrm{c}$ & $7.667 \mathrm{~d}$ & $6.138 \mathrm{e}$ & $5.287 \mathrm{f}$ \\
\hline \multicolumn{9}{|c|}{ Straw yield $(\mathrm{t} / \mathrm{ha})$} \\
\hline Irrigate every 4 days $\left(\mathrm{I}_{1}\right)$ & $11.090 \mathrm{a}$ & $10.870 \mathrm{a}$ & $10.835 \mathrm{a}$ & $10.795 a$ & $11.970 \mathrm{a}$ & $11.750 \mathrm{a}$ & $11.717 \mathrm{a}$ & $11.675 \mathrm{a}$ \\
\hline Irrigate every 8 days $\left(\mathrm{I}_{2}\right)$ & $10.845 a$ & $10.555 \mathrm{a}$ & $9.925 \mathrm{ab}$ & $8.775 \mathrm{c}$ & $11.725 \mathrm{a}$ & $11.435 \mathrm{a}$ & $10.805 \mathrm{ab}$ & $9.655 \mathrm{bc}$ \\
\hline Irrigate every 12 days $\left(\mathrm{I}_{3}\right)$ & $9.145 \mathrm{bc}$ & $8.353 \mathrm{~cd}$ & $7.357 \mathrm{de}$ & $6.482 \mathrm{e}$ & $10.025 \mathrm{bc}$ & $9.233 \mathrm{~cd}$ & $8.237 \mathrm{de}$ & $7.362 \mathrm{e}$ \\
\hline
\end{tabular}


The interaction effect between PGRs and rice cultivars are presented in Table 13. Data revealed that Giza 179 cultivar treated by Cytokinin gave the highest grain yield whereas the lowest grain yield was recorded with Giza 177 cultivar under control treatment. Also, rice plant which treated by PGRs showed an increase in grain yield ( $\mathrm{t} / \mathrm{ha}$ ) as compared with control.Singh and Sing (1980), reported varietal differences among the cultivar for moisture stress.

Table 13. Grain yield (t/ha) and straw yield (t/ha) as affected by the interaction between different growth regulators and two rice cultivars in 2015 and 2016 seasons.

\begin{tabular}{|c|c|c|c|c|}
\hline \multicolumn{5}{|c|}{ Grain yield (t/ha) } \\
\hline \multirow{3}{*}{ Irrigation interval } & \multicolumn{4}{|c|}{ Rice cultivars } \\
\hline & \multicolumn{2}{|c|}{2015 season } & \multicolumn{2}{|c|}{2016 season } \\
\hline & \multicolumn{4}{|c|}{ Giza 177 Giza 179 Giza 177 Giza 17} \\
\hline Spray with cytokine. & $8.657 \mathrm{c}$ & $9.477 \mathrm{a}$ & $9.167 \mathrm{c}$ & $9.987 \mathrm{a}$ \\
\hline Spray with ABA. & $8.042 \mathrm{de}$ & & $8.552 \mathrm{de}$ & $9.629 b$ \\
\hline Spray with proline & $7.506 \mathrm{fg}$ & $8.243 \mathrm{~d}$ & $8.016 \mathrm{fg}$ & $8.753 \mathrm{~d}$ \\
\hline Control (Tap water spray) & $7.206 \mathrm{~g}$ & $7.722 \mathrm{ef}$ & $7.716 \mathrm{~g}$ & $8.232 \mathrm{ef}$ \\
\hline \multicolumn{5}{|c|}{ Straw yield $\mathrm{t} / \mathrm{ha}$} \\
\hline Spray & $9.924 b$ & $10.796 \mathrm{a}$ & $10.804 \mathrm{~b}$ & $11.676 \mathrm{a}$ \\
\hline Spray & $9.260 \mathrm{c}$ & $10.592 \mathrm{a}$ & $10.140 \mathrm{c}$ & $11.472 \mathrm{a}$ \\
\hline Spray & $8.866 \mathrm{~d}$ & $9.879 \mathrm{~b}$ & $9.746 \mathrm{~d}$ & $10.759 b$ \\
\hline Control (Tap water spray) & $8.173 \mathrm{e}$ & $9.194 \mathrm{c}$ & $9.053 \mathrm{e}$ & $10.074 \mathrm{c}$ \\
\hline
\end{tabular}

The interaction effect among various irrigation intervals, the two rice cultivars and different plant growth regulators in grain yield are listed in Table 14. Data indicated a significant differences between the two cultivars in grain yield under both different irrigation intervals and plant growth regulators were observed. Moreover, the greatest grain yield was obtained from Giza179 cultivar when irrigated every 4 days under different PGRs and control while the same cultivar irrigated every 8 daysand treated with Cytokinin gave nearly the same grain yield as irrigated every 4 days. It might be due to role of cytokinin for relief the injury of shortage of water.Under water stress while ABA cause an increase in root depth and distribution which led to improve the uptake of both water and nutrients. Also, ABA increase cell division and elongation in both roots and shoots. On the other side, ABA minimizing the chlorophyll content and cause early senescence of leaves specially at heading. From the data in the same Table, it can be easily noticed that there was not any significant difference between the grain yield of Giza179 cultivar under the irrigation every 4-days and 8-days intervals when treated with cytokinin. It means that cytokinin cause extension of irrigation intervals from 4-days up to irrigation every 8 days without any significant reduction in the yield as well as saving reasonable amount of irrigation water.

Table 14.Grain yield (t/ha) as affected by the interaction between different irrigation intervals, two rice cultivars and different growth regulators in 2015 and 2016 seasons.

\begin{tabular}{|c|c|c|c|c|c|}
\hline \multirow{3}{*}{ Irrigation interval } & \multirow{3}{*}{ Variety } & \multicolumn{4}{|c|}{ Grain yield (t/ha) } \\
\hline & & \multicolumn{4}{|c|}{$\begin{array}{c}\text { Rice cultivars } \\
2015 \text { season }\end{array}$} \\
\hline & & Cytokinin & ABA & Proline & Control \\
\hline \multirow[t]{2}{*}{ Irrigation every 4 days $\left(\mathrm{I}_{1}\right)$} & Giza177( $\left(V_{1}\right)$ & $9.070 \mathrm{bc}$ & $9.000 \mathrm{~b}-\mathrm{d}$ & $8.990 \mathrm{~b}-\mathrm{d}$ & $8.900 \mathrm{~b}-\mathrm{e}$ \\
\hline & Giza179 $\left(V_{2}\right)$ & $10.307 \mathrm{a}$ & $10.220 \mathrm{a}$ & $10.220 \mathrm{a}$ & $10.000 \mathrm{a}$ \\
\hline \multirow[t]{2}{*}{ Irrigation every 8 days $\left(\mathrm{I}_{2}\right)$} & Giza177( $\left(V_{1}\right)$ & $9.000 \mathrm{~b}-\mathrm{d}$ & $8.500 \mathrm{~b}-\mathrm{f}$ & $8.200 c-f$ & $8.000 \mathrm{~d}-\mathrm{f}$ \\
\hline & Giza179 $\left(\mathrm{V}_{2}\right)$ & $10.200 \mathrm{a}$ & $9.450 \mathrm{ab}$ & $8.580 \mathrm{~b}-\mathrm{f}$ & $8.330 \mathrm{c}-\mathrm{f}$ \\
\hline \multirow[t]{3}{*}{ Irrigation every 12 days $\left(\mathrm{I}_{3}\right)$} & Giza177( $\left(V_{1}\right)$ & $7.900 \mathrm{f}$ & $6.627 \mathrm{~g}$ & $5.327 \mathrm{hi}$ & $4.717 \mathrm{i}$ \\
\hline & Giza179( $\left.V_{2}\right)$ & $7.920 \mathrm{ef}$ & $7.687 \mathrm{f}$ & $5.930 \mathrm{gh}$ & $4.837 \mathrm{i}$ \\
\hline & \multicolumn{5}{|c|}{2016 season } \\
\hline \multirow[t]{2}{*}{ Irrigation every 4 days $\left(\mathrm{I}_{1}\right)$} & Giza177( $\left(V_{1}\right)$ & $9.580 \mathrm{~b}-\mathrm{d}$ & $9.510 \mathrm{~b}-\mathrm{d}$ & $9.500 \mathrm{~b}-\mathrm{d}$ & $9.410 \mathrm{~b}-\mathrm{d}$ \\
\hline & Giza179 $\left(V_{2}\right)$ & $10.817 \mathrm{a}$ & $10.730 \mathrm{a}$ & $10.730 \mathrm{a}$ & $10.510 \mathrm{ab}$ \\
\hline \multirow[t]{2}{*}{ Irrigation every 8 days $\left(\mathrm{I}_{2}\right)$} & Giza177( $\left(V_{1}\right)$ & $9.510 \mathrm{~b}-\mathrm{d}$ & $9.010 \mathrm{c}-\mathrm{e}$ & $8.710 \mathrm{de}$ & $8.510 \mathrm{de}$ \\
\hline & Giza179( $\left.V_{2}\right)$ & $10.710 \mathrm{a}$ & $9.960 \mathrm{a}-\mathrm{c}$ & $9.090 \mathrm{c}-\mathrm{e}$ & $8.840 \mathrm{c}-\mathrm{e}$ \\
\hline \multirow[t]{2}{*}{ Irrigation every 12 days $\left(\mathrm{I}_{3}\right)$} & Giza177( $\left(V_{1}\right)$ & $8.410 \mathrm{de}$ & $7.137 f$ & $5.837 \mathrm{gh}$ & $5.227 \mathrm{~h}$ \\
\hline & Giza179(V $\left.V_{2}\right)$ & $8.430 \mathrm{de}$ & $8.197 \mathrm{e}$ & $6.440 \mathrm{fg}$ & $5.347 \mathrm{~h}$ \\
\hline
\end{tabular}

\section{Straw yield (t/ha):}

Data in Table (10) indicated that rice plants grown under irrigation every 4 and 8 days statistically promoted their straw production and gave the highest straw yield compared with plants which were grown under irrigation every 12-days intervals. Lower straw yield could be as a result of water stress imposed at tillering which cause a decrease in photosynthesis, translocation rate and dry matter accumulation. Similarly tillersper unit area, plant height, number of leaves.

Data in the same table revealed that rice Giza 179 cultivar showed superiority in their straw yield (ton/ha) compared to Giza 177rice cultivar in both seasons of study. These results could be mainly due to vigorous growth of Giza179rice cultivar in vegetative stage which has vigorous root system, big canopy, high leaf area index and thus dry matter production compared to Giza 177 cultivar by the other meaning it might be due to the genetic back ground.
Straw yield of rice as influenced by different plant growth regulators (PGRs) is presented in Table 10. Data indicated that spraying Cytokininmarkedly surpassed ABA and proline in straw yield and produced the greatest value followed by $\mathrm{ABA}$ and proline as compared with control in the two studied seasons.

Data in Table 11 show a highly significant interaction was recorded between different irrigation intervals and the two tested rice cultivars in straw yield in both studied seasons. Data indicated that Giza 179 cultivar recorded the highest value of straw yield under irrigation every 4 days followed by irrigation every 8 days in both seasons of study. On the other hand, the lowest value of straw yield was recorded with Giza 177cultivar under irrigation every 12 daysin the both seasons of study.

Straw yield as influenced by the interaction between different irrigation intervals and variousPGRs is present in Table 12.Data substantiated that there 
weren't any significant differences among all the PGRs and control under irrigation every 4 days in the both seasons. Application of Cytokininunder the irrigation every 4 and 8 -days intervals gave the highest straw yield without any significant difference between them. On contrast the lowest values of straw yield were obtained when rice plant irrigated every 12 days with control. The current findings are similarity with those reported by Jianchang Yang et al., (2000); Morris, et al., (2005) and SalehiGharaviran, et al., (2014).

The interaction effect between PGRs and rice cultivars is presented in Table 13. Data revealed that Giza 179 cultivarsprayed with Cytokiningave the highest straw yield followed by ABA without any significant difference between them, whereas the lowest straw yield was recorded with Giza 177 cultivar under control treatment.

\section{CONCLUSION}

1- According to the previous results, it can be concluded that sprayed Giza179 rice cultivar by cytokinin prolonged the irrigation interval from 4 days up to 8 days that led to save reasonable amount of irrigation water.

2- Sprayed both Giza179 cultivar and Giza177 rice cultivar by the three-plant growth regulating substances relief the injury of water stress (irrigation every 12 days) as compared with control treatment. The most effective one was cytokinin which increase the yield by about $3.2(\mathrm{t} / \mathrm{ha})$ which equal 1.34 ( $\mathrm{t} / \mathrm{fed}$ ) followed by ABA which increase the yield by about $1.9(\mathrm{t} / \mathrm{ha})$ which equal $0.8(\mathrm{t} / \mathrm{fed})$.

3- Giza179 rice cultivar more tolerant to water shortage than Giza177 rice cultivar and responded more to cytokinin application.

These results are very important for the farmers whose have shortage of water in rice fields.

Finally, this study needed to more study to reach the best results about using different growth regulators under different water stress.

\section{REFERENCES}

Abd Allah, A. A.; A.A.A. Mohamed and M. M. GabAllah. (2009). Genetic studies of some physiological and shoot characters in relation to drought tolerance in rice. J. Agric. Res. Kafr-El Sheikh Univ., 35 (4).

Bahattacharjee, D.P., Krishnayya, G.R. and Ghosh, A.K. (1973) Analyses of Yield Components andproductive Efficiency of Rice Varieties under SoilMoisture Deficit. Indian Journal of Agronomy, 16, 314-343.

Bergez, J.E. and Nolleau, S. (2003). Maize Grain Yield Variability between Irrigation Stands: A Theoretical Study. Agricultural Water Management, 60, 43-57.

Black, C.A; D.D. Evans; L.E. Ensminger and f. E. Clark (1965). Methods of soil analysis. Part 2-Chemical and microbiological properties. American Soc. of agronomy, Inc., Publisher, Madison. Wisconsin, USA.

Boonjung, H. and Fukai, S. (1996). Effects of Soil Water Deficit at Different Growth Stages on Rice Growth and Yield Under Upland Conditions. Field Crops Research, 48, 47-55.
Caballero, J.I., C.V. Verduzco, J. Galan and E.S.D. Jimenez, (2005). Proline accumulation as a symptom of water stress in maize: A tissue differentiation requirement. Journal of Experimental Botany, 39(7): 889-897.

Cabuslay, G.S., O. Ito and A.A. Alejar, (2002). Physiological evaluation of responses of rice (Oryza sativa L.) to water deficit. Plant Science, 163(4): 815-827.

Čatský, J., Pospíšilová, J., Kamínek, M., Gaudinová, A., Pulkrábek, J., Zahradníček, J. (1996). Seasonal changes in sugar beet photosynthesis as affected by exogenous cytokinin N6-(m-hydroxybenzyl) adenosine. - Biol. Plant. 38: 511-518, 1996.

Cowan, A.K., Cairns, A.L.P., Bartels-Rahm, B. (1999). Regulation of abscisic acid metabolism: towards a metabolic basis for abscisic acid-cytokinin antagonism. - J. Exp. Bot. 50: 595-603.

De Datta, S.K., Abilay, W.P. and Kalwar (1973) Water Stress Effect on Flooded Tropical Rice. Water Management in Philippines Irrigation System Research and Operation, 16-36.

El- Refaee. I. S., R.N. Gorgy and T. F. Metwally. (2012). Response of some rice cultivars to plant spacing for improving grain yield and water productivity under different irrigation intervals. Alex. J. Agric. Res. 57. (1): $1-14$.

Gomes, A.K and A.A Gomes. (1984). Statistical procedures of Agricultural Research.2 and ed. Jahn Wiley Sons, New York.

Hare, P.D., Cress, W.A., Van Staden, J. (1997). The involvement of cytokinins in plant responses to environmental stress. - Plant Growth Regul. 23: 79103, 1997.

Hany S. Gharib, T.F. Metwally, S.S. Naeem and E.E. Gewaily. (2011). Influence of Some Stimulating Compounds and Nitrogen Fertilizer Levels on Growth and Yield of Hybrid Rice. Zagazig J. Agric. Res., Vol.38 No. (1) 2011.

Hashem, I. M., E. S. Naeem, T. F. Metwally and H. M. El Sharkawi (2016). Enhancement of lodging resistance and productivity of rice using growth regulators at different nitrogen levels. Journal of Plant Breeding and Crop Science. Vol. 8(3), pp. 3444, March, 2016.

Howida B. El-Habet., (2014). Irrigation regime and potassium levels effects on yield of some rice genotypes, water use efficiency (wue) and economic returns. vol. 5 (3): 383- 399.

Hu, H., M. Dai, J. Yao, B. Xiao, X. Li, Q. Zhang and L. Xiong, (2006). Overexpressing a NAM, ATAF and CUC (NAC) transcription factor enhances drought resistance and salt tolerance in rice. Proceedings of the National Academy of Sciences of the United States of America, 103(35): 12987-12992.

Jianchang Yang; Shaobing Peng; Romeo M. Visperas; Arne L. Sanico; Qingsen Zhu and Shiliang Gu. (2000). Grain filling pattern and cytokinin content in the grains and roots of rice plants. Plant Growth Regulation 30: 261-270.

Kamínek, M., Motyka, V., Vaňková, R. (1997). Regulation of cytokinin content in plant cells. - Physiol. Plant. 101: 689-700, 1997.

Kermode, A.R., M.Y. Oishi and J.D. Bewleym, (1989). Regulatory roles for desiccation and $\mathrm{ABA}$ in seed development. A comperision of the evidence from whole seeds and isolated embryos. In: Stanwood P.C. and Mcdonald M.B.(eds), CSSA special publication, pp: 23-50. 
Khush, G.S. (2005) What It Will Take to Feed 5.0 Billion Rice Consumers in 2030. Plant Molecular Biology, 59, 1-6.

Meinzer, F.C., Grantz, D.A., Smit, B. (1991). Root signals mediate coordination of stomatal and hydraulic conductance in growing sugarcane. - Aust. J. Plant Physiol. 18: 329-338.

Metwally, T. F.; E.S. Naeem; I.M. Hashem and H. M. ElSharkawi (2016). Impact of the Interaction Effect between Nitrogen Fertilizer and Auxin Application on Performance of Egyptian Hybrid Rice.

Morris, R.D., D.G. Blevins, J.T. Dietrich, R.C. Durly, S.B. Gelvin, J. Gray, N.G. Hommes, M. Aminek, L.J. Mathews, R. Meilan, T.M. Reinbott and L. Sagavendra-Soto, (2005). Cytokinins in plant physiol., 20: 621-637.

Naqvi, S.S.M. (1999). Plant hormones and stress phenomena. - In: Pessarakli, M. (ed.): Handbook of Plant and Crop Stress. Pp. 709-730. Marcel Dekker, New York - Basel 1999.

Nooden, L.D., (1988).Abscic acid, auxin, and other regulators of senesce. Academic Press, San Diego, pp: $329-368$

POSPÍSILOVÁ, J., H. SYNKOVÁ and J. RULCOVÁ. (2000). Cytokinins and water stress BIOLOGIA PLANTARUM 43 (3): 321-328, 2000.

Rabas, A.R. and C.E. Martin, (2003). Movement of water from old to young leaves in three species of succulents. Annals of Botany, 92(4): 529-536.

Rahman, M.T., Islam, M.T. and Islam, M.O. (2002). Effect of Water Stress at Different Growth Stages on Yield and Yield Contributing Characters of Transplanted Aman Rice. Pakistan Journal of Biological Sciences, 5, 169-172.

Saha S, Nagar PK and Sircar PK (1986). Cytokinin concentration gradient in the developing grains and upper leaves of rice (Oryza sativa) during grain filling. Can J Bot 64: 2068-2072.

SalehiGharaviran, L., Nabizadeh, E., Yezdanseta, S (2014). Study of Impacts of Plant Growth Regulators Foliar Spray on Yield and Yield Components of Wheat cv. Zarrin at Different Growth Stages. Advances in Environmental Biology, 8(1) January 2014, Pages: 134-138.

Shani, U. and Dudley, L.M. (2001). Field Studies of Crop Response to Water and Salt Stress. Soil Science. Society of America Journal, 65, 1522-1528.
Singh U.P. and Sing, K. (1980). IR5178-1-1-4 an Outstanding Drought Tolerant Line. International Rice Research Newsletter, 5, 9.

Soejima, H., Sugiyama, T., Ishihara, K. (1992). Changes in cytokinin activities and mass spectrometric analysis of Cytokinins in root exudates of rice plant (Oryza sativa L.). Comparison between cultivars Nipponbare and Akenohoshi. - Plant Physiol. 100: 1724-1729, 1992.

Sokoto M. B. and A. Muhammad (2014). Response of Rice Varieties to Water Stress in Sokoto, Sudan Savannah, Nigeria. Journal of Biosciences and Medicines, 2014, 2, 68-74.

Solamani, A., Sivakumar, C., Anbumani, S., Suresh, T. \&Arumugam, K. (2001). Role of plant geowth regulators on rice production: A review. Agric. Rev., 23:33-40.

Tantawi, B.A. and Ghanem, S.A. (2001) Water Use Efficiency in Rice Culture. Agricultural Research Center, Giza (Egypt). CIHM-Optin Mediterraneennes, 40, 39-45.

Waller, R.A. and D.B. Ducan, (1969). Bayes rule for the Symmetric MallipleComason problem. J. Am. Stat, Assoc., 64: 1484-1499.

Xie, Z., D. Jiang, T. Dai and W. Cao, (2004). Effect of exogenous ABA and cytokinin on leaf photosynthesis and grain protein accumulation in wheat ears cultured in vitro. Plant Growth Regul., 44: 25-32.

Yang, J., J. Zhang, Z. Wang, Q. Zhu and L. Liu, (2002). Abscisic acid and cytokinins in the root exudates and leaves and their relationship to senescence and remobilization of carbon reserves in rice subjected to water stress during grain filling. Planta, 215: 645652.

Yang, J., J. Zhang, Z. Wang, Q. Zhu, (2003). Hormones in the grains in relation to sink strength and postanthesis development of spikelets in rice. Plant Growth Regul., 41: 185-195.

Zhang Jianhua, Jia, Yang, and M. Ismail (2006). Role of $\mathrm{ABA}$ in integrating plant responses to drought and salt stresses. Field Crops Research 97 (2006) 111119 .

Zwart, S.J. and Bastiaanssen, W.G.M. (2004). Review of Measured Crop Water Productivity Values for Irrigated Wheat, Rice, Cotton and Maize. Agricultural Water Management, 69, 115-133.

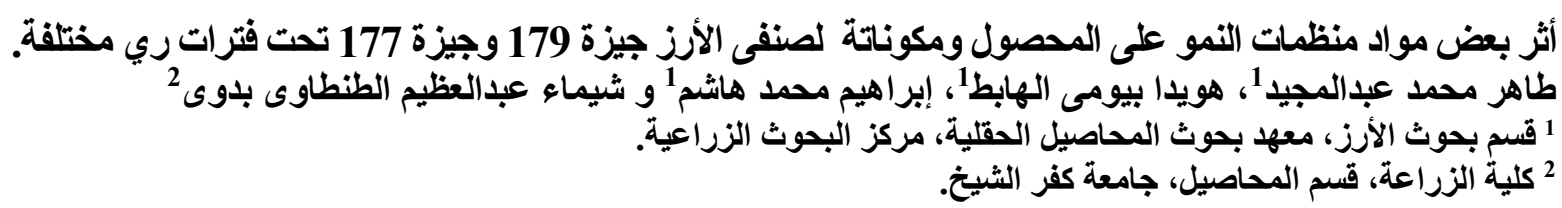

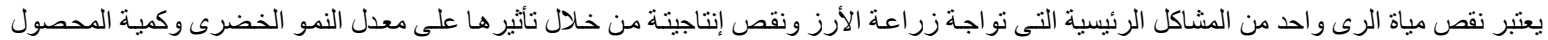

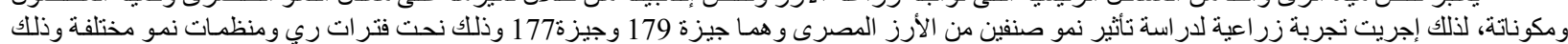

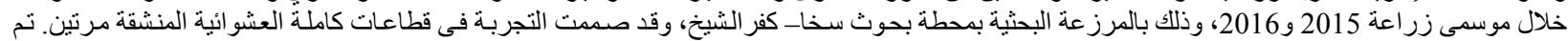

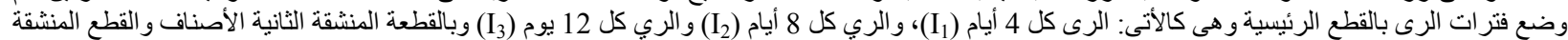

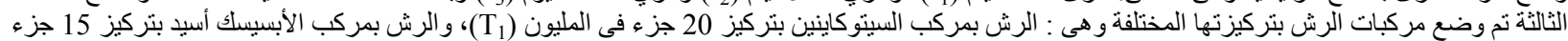

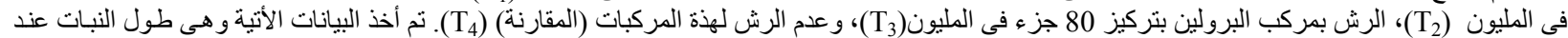

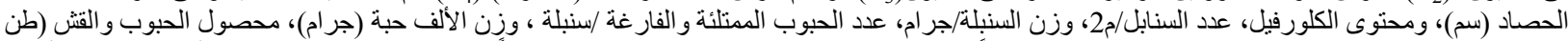

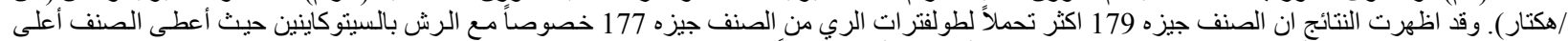

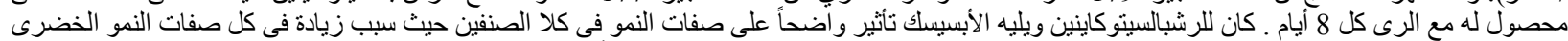

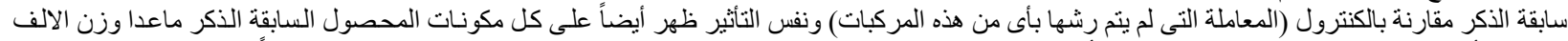

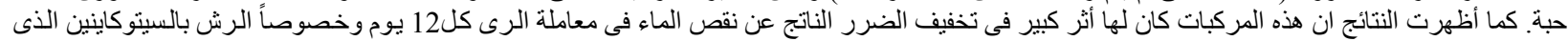

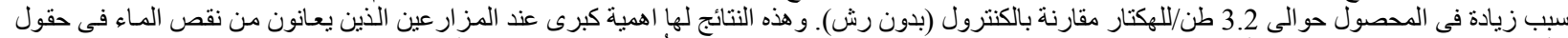

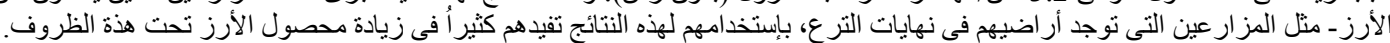

